\title{
A Behavioural Brand Evaluation Typology to Measure Brand Performance over Time
}

\author{
Abas Mirzaei ${ }^{1}$, Helen (Elham) Siuki ${ }^{1}$, Chris Baumann $^{1} \&$ David Gray ${ }^{1}$ \\ ${ }^{1}$ Macquarie University, Australia \\ Correspondence: Abas Mirzaei, Macquarie University, Australia. E-mail: abas.mirzaei@mq.edu.au
}

Received: July 13, 2015

Accepted: August 3, $2015 \quad$ Online Published: September 18, 2015

doi:10.5539/ijbm.v10n10p26

URL: http://dx.doi.org/10.5539/ijbm.v10n10p26

\begin{abstract}
Brands are built over time, but are measured on short-term basis. This paper provides a new long-term based platform to evaluate the performance of a brand. It is built on a long-term brand health measure and monitors the performance of a brand over time. Depending on the extent to which a brand is healthy and powerful over time, a long-term oriented behavioural brand evaluation typology is developed which categorises brands into four types: Emergers, Strugglers, Dynamos, and Disoriented brands. This is a longitudinal study, examining the proposed typology in four service industries: banking, department stores, airlines, and insurance from 2001 to 2011. The findings suggest that Dynamos are the healthiest and most powerful brands, while Strugglers are the unhealthiest and least powerful brands. We provide practical strategies and actions to be taken for each type of brand.
\end{abstract}

Keywords: brand equity, brand health index, marketing accountability, brand performance, branding

\section{Introduction}

Over the last few years, brand managers have been under increasing pressure to objectively account for the contribution of their brand building actions. MSI (2000-2010) placed marketing accountability as one of its key research priorities, and a wide range of brand performance measures developed in response to this calls. Brand performance measures vary from subjective, survey-based measures, to objective and market-based, and financial measures.

Subjective, survey-based measures are effective diagnostic tools for managers, however consumers' ability in reflecting their preferences can influence the reliability of the results (Park \& Srinivasan, 1994). Market-based, objective measures of brand performance, on the other hand, are based on consumer purchase behaviour, and less contingent to human errors in data collection, therefore more auditable and reliable. Moreover objective, behavioural measures are more relevant to senior managers (Kumar, Pozza, \& Gonesh, 2013) since behavioural measures such as sales, and market share are associated with financial measures such as return which is the language of managers. Depending on the circumstances and the objectives, managers may apply different metrics to evaluate the brand performance, mostly, a combination of survey data, market figures, and financial results.

Regardless of the type of performance measure being used, a major limitation of existing measures is their short-term orientation. Metrics that measure the performance of a brand based on short-term results, do not encompass the lagged impacts of marketing actions. It has been well-acknowledged in the literature that the results of brand building actions can go beyond the current term and appear in the future (Mizik \& Jacobson 2007). Despite the fact that brands are built over time, brand performance is evaluated over short-term (Lodish \& Mela, 2007). In other words, managers are hired to build brands over time, but they are fired on short-term basis (Bruce et al., 2012). Therefore it is important to be long-term oriented in order to evaluate the lagged outcome of branding actions.

In this paper, we apply a new brand performance measure with long-term orientation, called "Brand Health Index", proposed by Mirzaei et al. (2015), and provide a new framework that evaluates brands based on their long-term performance encompassing the lagged impacts. We propose a typology of behavioural brand evaluation (BBE) which enables managers to assess and monitor the health of their brands over time. We classify brands into four categories, namely, Dynamos, Strugglers, Emergers, and Disoriented brands. Throughout its life, a brand can face each of the above stages. We provide practical and effective marketing and brand building 
strategies for each category.

\section{Brand Measurement: Literature Review}

To evaluate the performance of a brand, a wide range of metrics and measures have been developed over the last few years. Brand equity as a main marketing asset has been proposed as a non-financial measure of brand performance. Aaker (1991), and Keller (1993), offer two well-accepted definitions of brand equity. Aaker (1991) defines brand equity as "a set of brand assets and liabilities linked to a brand, its name and symbol that add to or subtract from the value provided by a product or service to a firm and/or to that firm's customers" (Aaker, 1991, p. 15). Aaker's (1991) definition, encompasses five key dimensions of brand equity including brand awareness, brand associations, brand quality, brand loyalty, and other properties, which can be classified as brand elements. Keller (1993), on the other hand, defines brand equity as "the differential effect of brand knowledge on consumer response to the marketing of the brand" (p. 2). Based on this definition, consumers react more strongly (positive/negative) to the marketing actions of brands that they are familiar with.

Although there is agreement on the definition of brand equity, the measurement of brand equity can be discussed from different perspectives. Three major perspectives are identified to measure brand equity (Keller \& Lehmann, 2006). A variety of subjective measures such as brand associations, awareness, and brand image are employed to measure the brand equity from a customer mindset perspective. Brand equity can also be measured based on market outcomes. Product-market metrics such as market share (Park \& Srinivasan, 1994) capture consumers purchase behaviour. Such measures are objective, and auditable. Compared to subjective measures, product market metrics contain incremental information to financial measures. Finally, on the brand value chain, measures such as Tobin's Q, market-to-book ration, or discounted cash flow measure the performance of an intangible asset like brand from a financial perspective (Tiwari, 2010). Among all three types of academic brand measurement classifications, product-market measures bridge the subjective outcomes to financial performance (Ailawadi et al., 2003). The aforementioned approaches to measuring brand equity can also be classified into two broader categories, namely, consumer-based brand equity (CBBE) and firm-based brand equity (FBBE) (Christodoulides \& De Chernatony, 2010). Brand equity, from a consumer perspective, positively influences consumer perceptions, purchase intentions (Rego, Billett, \& Morgan, 2009). Additionally, it reduces consumers' searching costs (Shankar, Azar, \& Fuller, 2008). Brand equity based on a firm perspective, affects consumers' price sensitivity (Erdem et al., 2002), and facilitates the expansion of market (Cabral, 2000). Branding can also be beneficial in the business-to-business context (Glynn, Brodie, \& Motion, 2012).

In addition to academic frameworks of measuring brand equity, there are some industry-based approaches to measuring brand equity and brand value (Mirzaei, Gray, \& Baumann, 2011). Interbrand, Y\&R, and BrandZ are some examples of consulting firms that provide measurements for brand equity and brand value. The weakness of the industry measures is that, in the main, they are not entirely reliable due to inconsistency in measurement methodology which often results in a considerable, (i.e. up to 450\%) variation in brand evaluation outcomes (Hanssens, 2011).

A major shortcoming of all existing measures of brand performance is their short-term orientation. Limiting the performance of branding actions to short-term results may damage the brand over long-term. This is due to the fact that to satisfy CEOs, brand managers focus on branding actions with short-term results (Lodish \& Mela, 2007). Short-term marketing actions such as price promotion have a negative impact on brand performance over long-term (Ataman, Van Heerde, \& Mela, 2010). Moreover, the impact of marketing and brand building actions may appear over long-term. On the brand value chain, the impact of branding actions first results in a change in consumers attitudes. The process from consumer attitude to consumer purchase behaviour may take some time to be reflected dollar value (Hanssens, Rust, \& Srivastava, 2009). Thus it is important to have a long-term orientation in measuring the performance of a brand. Such a long-term oriented approach which captures the lagged impacts and evaluate the performance of a brand encompassing the current and lagged outcomes.

In this paper, we apply a new measure of brand performance with long-term orientation, called brand health index (BHI), and develop a behavioural brand evaluation typology which classifies brands into four categories based on their long-term performance.

\subsection{Brand Health Index and Brand Powerfulness}

Marketing actions have a lagged impact which will appear in the future (Clarke, 1976; Mizik \& Jacobson, 2008). The initial outcome of any effective marketing action first influences consumers' preferences and attitudes. It is crucial to positively influence consumers' attitudes, however any change in attitude must be reflected in purchase behaviour and ultimately financial returns. It has been demonstrated in the literature that it may take several periods until the results of any change in attitudes and feelings is translated in "concrete" sales numbers 
(Hanssens et al., 2009). Mirzaei et al. (2015) propose a new measure, called brand health index (BHI) that considers the lagged impact of marketing actions, and evaluates the performance of a brand on a long-term basis. They define a healthy brand as a brand that experiences a sustained positive sales growth over time (Mirzaei et al., 2015). BHI has two main components, namely the growth of sales, and the volatility in sales growth over time. These two drivers are grounded on the long-term brand value model, proposed by Keller and Lehmann (2009).

A variety of marketing actions can be practised to boost brand sales over the short-term. For instance, price cuts, discounts, promotional offerings, can increase the sales due to the fact that consumers may purchase extra and stock it for the next round (Madden, 2006). However over the long-term, if a brand is continuously appealing to its customers, it is expected that the brand will experience a continuous persistent sales growth.

Following Mirzaei et al. (2015), we estimate the brand health index as follow:

$$
\begin{gathered}
\text { Brand Health Index }{ }_{i t}\left(B H I_{i t}\right)=\text { Sustained Growth }=\frac{\sum_{t-T}^{t} \text { Growth }_{i t}}{S D_{g i(t-T, t)}} \\
\text { Growth }_{i t}=\frac{\text { (sales } \left._{i t}-\text { Sales }_{i t-1}\right)}{\text { Sales }_{i t-1}} \\
S D_{g i(t-T, t)}=\sqrt{\frac{\sum_{t-T}^{t}\left(\text { Growth }_{i t}-\overline{\text { Growth } \left._{l(t-T, t)}\right)^{2}}\right.}{T-1}}
\end{gathered}
$$

Where growthit is the growth of firm $i$ at time $t, \operatorname{SDgi}(t-\mathrm{T}, \mathrm{t})$ represents the standard deviation of growth for brand $\mathrm{i}$ at time $\mathrm{t}-\mathrm{T}$ to $\mathrm{t}$. In equation 1 , standard deviation of sales growth represents the sales growth volatility. Therefore brands with highest cumulative sales growth and lowest sales growth volatility are the healthiest brands.

A brand can be healthy, but not necessarily strong and powerful for reasons such as operating in a niche market, or being new to the market. Since the proposed measure of brand health is a scale-free measure, it does not consider the sales volume and sales value differences between brands although it is important in valuing brands (Mizik \& Jacobson, 2009). For instance, Ailawadi et al. (2003), multiplied price difference by a firm's sales in order to measure revenue premium as a measure of brand equity. As another example, Mizik, and Jacobson (2009) multiplied a brand value coefficient by a firm's sales to value a branded business. Therefore to capture the pure brand powerfulness we multiply the brand health index by the brand's average market share over the study period as a proxy for the firm size and its past performance.

We compute brand powerfulness as follow:

$$
\begin{gathered}
\text { Brand Powerfulness }_{i t}=\text { BHI }_{i t} * \text { Average Market Share } \\
i(t-T, t) \\
B P_{i t}=\left(\frac{\Sigma_{t-T}^{T} \text { Growth }_{\text {rew }}}{S D_{g i(t-T, t)}}\right) \times\left(\frac{\sum_{t-T}^{T} \text { Market Share }_{i(t-T, t)}}{T}\right)
\end{gathered}
$$

Average market share in the above equation is constant throughout the study period for each brand, and does not change over time. It is considered as a proxy for firm's sales differences.

In the next section we develop a behavioural brand evaluation typology based on brand healthiness and powerfulness. This typology provides managers with an objective framework to track, and monitor the healthiness of their brands over time. More importantly it provides significant insights and contributes to the brand management literature, enabling managers to make effective situational decisions based on the status of their brand in the marketplace.

\subsection{Behavioural Brand Evaluation Typology}

Savvy customers and competitive marketplace are among the greatest challenges for managers (Keller 2013). In such an environment, not only it is important to remain healthy and powerful, but also it is crucial to take into account the competitors' position in the market. Therefore managers must monitor their performance in relation to competitors. To map the healthiness and powerfulness of brands in comparison to their competitors, we develop a behavioural brand evaluation (BBE) typology. This enables managers to track their relative brand health and powerfulness over the time in comparison to compatitors, and employ effective strategies depending on their brand type.

As shown in Figure 1, the proposed model classifies brands into four categories based on different combinations of two main constructs, healthiness, and powerfulness. The four categories are Disoriented, Dynamos, Strugglers, 
and Emergers. These are new terms and we introduce them here. There are also brands somewhere in between these main categories. Table 1 provides a summary explanation for each category.

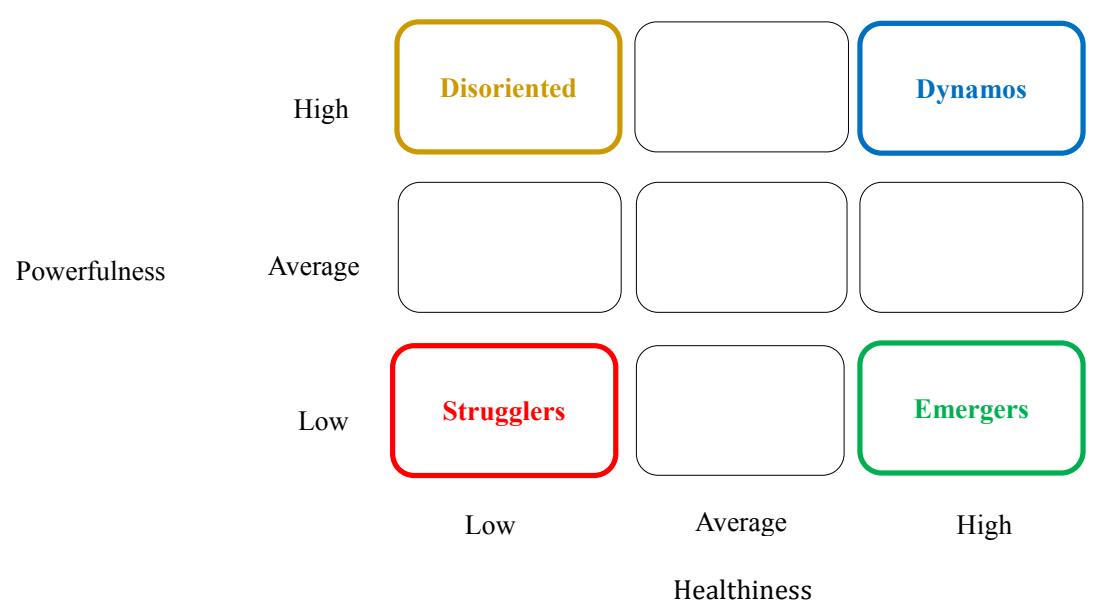

Figure 1. Behavioral brand evaluation typology

Table 1. Conceptual brief of behavioural brand evaluation typology

\begin{tabular}{|c|c|}
\hline Cor & tion \\
\hline Dynamos & $\begin{array}{l}\text { ands in this category are those that constantly have responded to customers' preferences. They have been able to adapt their } \\
\text { vices, products, and marketing actions to suit their target markets' preferences. Dynamos are performing very well, quite } \\
\text { althy, have a promising future, and a considerable market share. Nike perfectly matches this category. A powerful, healthy } \\
\text { and. Completely on the right track in terms of dynamically responding to customers' needs. }\end{array}$ \\
\hline Emergers & $\begin{array}{l}\text { Inds in this category are continuously and increasingly appealing to their target market. With a high brand potential their } \\
\text { are is promising. Brands in this category are healthy but not quite powerful since most are young brands with a small } \\
\text { rket share. Emergers can turn to Dynamos through stable ascending brand health over the years. JetBlue in the US airline } \\
\text { ustry is an example of this category. Small market share, but quite healthy with constant sales growth. The future is } \\
\text { mising for JetBlue if it continuous to adapt its services to suit its consumers' tastes. }\end{array}$ \\
\hline Strugglers & $\begin{array}{l}\text { Brands in this category are the unhealthiest brands with a low level of powerfulness. These are the brands that have been } \\
\text { struggling in touching customers' hearts and appealing to them. Brands in this category are mainly young with no bright } \\
\text { future. They haven't been able to effectively address customers' needs neither in the past, nor in the current term, and are } \\
\text { heading towards failure. SkyWest and Fifth Third are examples of brands in this category. }\end{array}$ \\
\hline Disoriented & $\begin{array}{l}\text { Brands in this field have been doing very well in the past for the period out of the study window. However, for the last } 10 \\
\text { years, they haven't been able to experience a stable sales growth. Brands in this category aren't healthy at this stage, but all } \\
\text { still powerful due to their past performance. Disoriented brands have failed to adapt their strategies and actions to market } \\
\text { changing needs. Without an effective plan to improve their brand health index, brands in this category will move towards the } \\
\text { Strugglers category. AIG in the insurance industry is an example of a Disoriented brand falling from market leader to an } \\
\text { unhealthy brand, losing most of its market share. Nokia in the smartphone arena could be considered as another example in } \\
\text { this category. }\end{array}$ \\
\hline
\end{tabular}

The proposed behavioural brand typology is different from the Boston Consulting Group (BCG) matrix in several ways. First, BCG has a short-term view in evaluation; however, BBE has a long-term orientation. BCG is a function of market share and growth, however BBE is a function of BHI and brand powerfulness. Since the unit of analysis in BBE is brand, and since building a brand is a long-term process, thus there is a need to evaluate brands over time. To highlight the importance of long-term orientation consider this example. In quarter 1, brand A has a low market share, and low sales growth. Based on BCG matrix, brand A is categorised as a Dog. Managers decide to spend on marketing actions in order to boost the sales. In quarter 2, brand A experiences a high sales growth due to temporary marketing efforts. This means brand A has moved to the Question mark category from Dogs in just one quarter. Applying BBE typology brand A will still remain in the same category for quarter 1 and 2. In other words, however a brand can experience sales growth over the short-term (one or two 
periods), but boosting their brand health index takes several periods since it's a long-term oriented measure.

Secondly, BCG considers the growth rate without taking into account the fluctuations in growth rates, however BBE considers both growth rates and growth rates fluctuations. As mentioned earlier, not only growth is important, but also the ability to maintain the growth is crucial.

Due to the main two differences mentioned above, BBE categorised brands differently compared to BCG. As a result the description of each category and the effective strategies to be undertaken by managers are different across BBE and BCG. As shown in Table 2, we have provided a visualised comparison for BCG and BBE. According to BCG, a brand with high market share and low growth is called a Cash Cow. A cash cow as a cash generator doesn't need the same level of support as before. The corresponding category for Cash Cow in BBE can be considered as Disoriented. A Disoriented brand is in trouble and is heading towards failure. It cannot be a cash generator since it is not healthy. Although for cash cow, it is recommended to not invest further and try to maximize the profit, for a disoriented brand, it is recommended to invest more and try to adopt new strategies to catch up with customers' needs. As another example, a question mark in BCG matrix, is called an Emmerger in BBE. An emerging brand has a promising future with a high potential as opposed to be a question mark. Overall, BBE typology can help managers to evaluate the position of their brand in the marketplace over a long-term horizon.

Table 2. A comparison of BCG matrix and BBE typology

\begin{tabular}{ll}
\hline Star (BCG) & Question Mark (BCG) \\
Dynamo (BBE) & Emmergers (BBE) \\
\hline Cash Cow (BCG) & Dogs (BCG) \\
Disoriented (BBE) & Strugglers (BBE) \\
\hline
\end{tabular}

\section{Data Description}

The empirical analysis of this paper is based on COMPUSTAT database. We compute brand health and brand powerfulness on a 9-year basis, since it is most associated timeframe with financial measures such as earning per share (EPS), and return on assets (ROA). We focus on services sector as the main contributor to GDP compared to manufacturing (Mirzaei et al., 2015). Four services industries were selected from the top 15 GDP contributing industries, namely airline, banking, insurance, and department store (Bureau of Economic Analysis 2013). To control for country-specific differences, this paper focuses only on one market. The US market is selected as a dynamic market with several brands in each industry. Moreover, a greater number of brands in the US market disclose their firm-specific information compared to other countries such as Germany, Japan, and Australia. We study a period from 2002 to 2011 encompassing the global financial crisis in 2007-2008. We compare the results for the period before and after the financial crisis.

\subsection{Empirical Analysis}

The majority of firms across all four industries have experienced a strong positive sales growth pre-GFC. However post-GFC, most industries were negatively influenced. As shown in figure 2, the least affected industry by GFC, among the four, is airline industry, whereas banking almost experience zero growth on average for the period after GFC. 


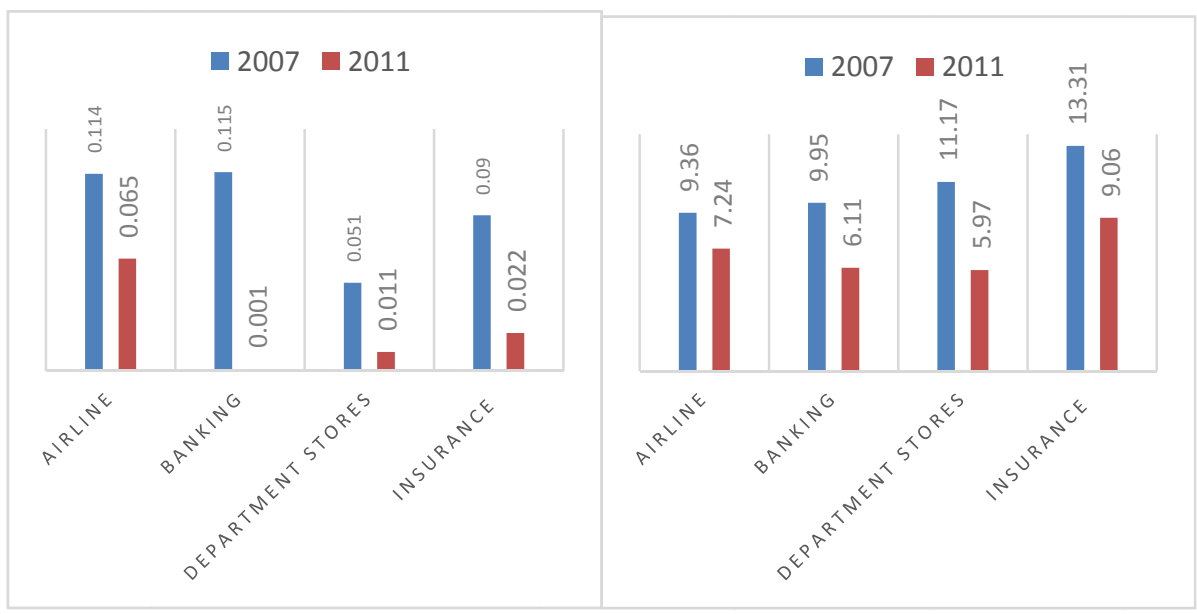

Figure 2. Industry-level descriptive statistics

On the brand typology map, as shown in Figure 3, which is based on relative brand health (RBH) and relative brand powerfulness (RBP), Delta has moved from a Disoriented brand in 2007 to a Dynamo in 2011. American Airlines on the other hand, has moved towards its failure from a Disoriented brand in 2007 to a Struggler in 2011. In relation to competitors, the health index for Southwest Airline has slightly increased for the period after GFC, although its level of powerfulness has decreased during the same period.
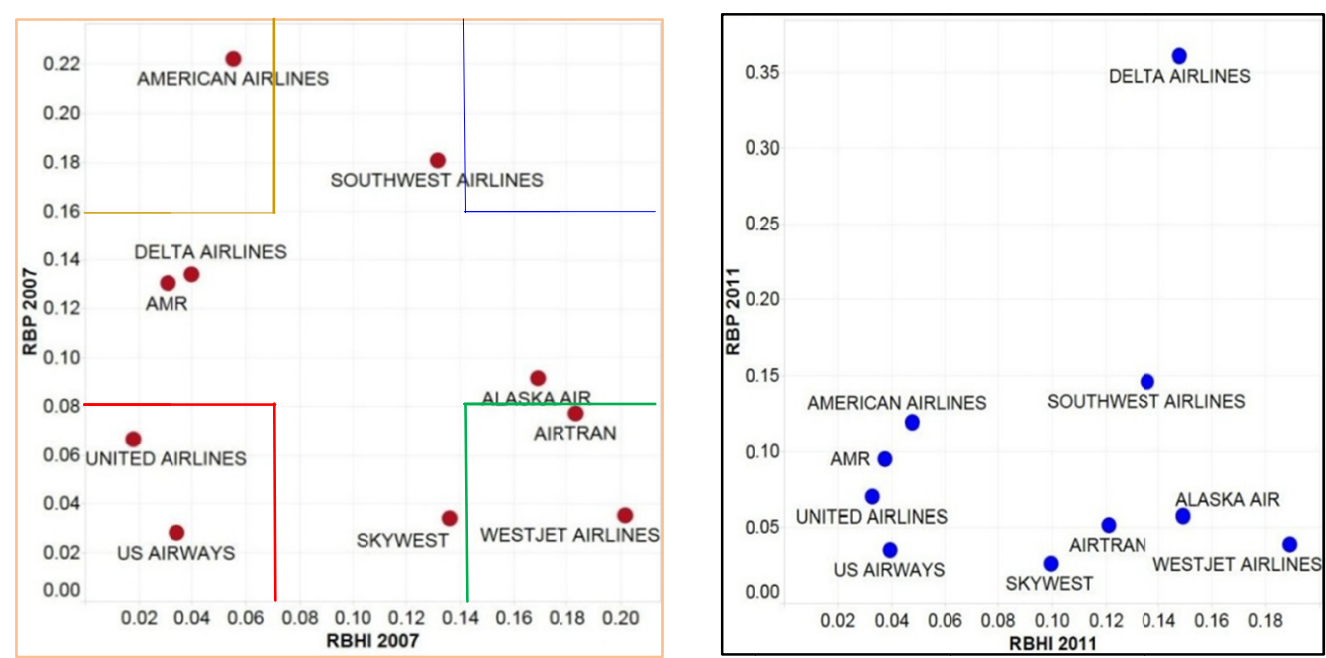

Figure 3. Behavioral brand evaluation typology, airline industry (pre and post GFC)

Note. RBP: Relative Brand Powerfulness; RBHI: Relative Brand Health Index.

In the banking industry, as shown in Figure 4, BB\&T and State Street are performing healthily and are classified as Emergers. Their position in the BBE map hasn't changed much pre-and post-GFC. Unlike BB\&T and State Street, brands such as SunTrust and Fifth Third have not been able to find their ways to customers' minds and feelings, and have moved back on the BBE map, being classified as Strugglers with an unclear future. They may end up being acquired by or joined with other brands if they cannot reconnect with their customers (including new ones). 

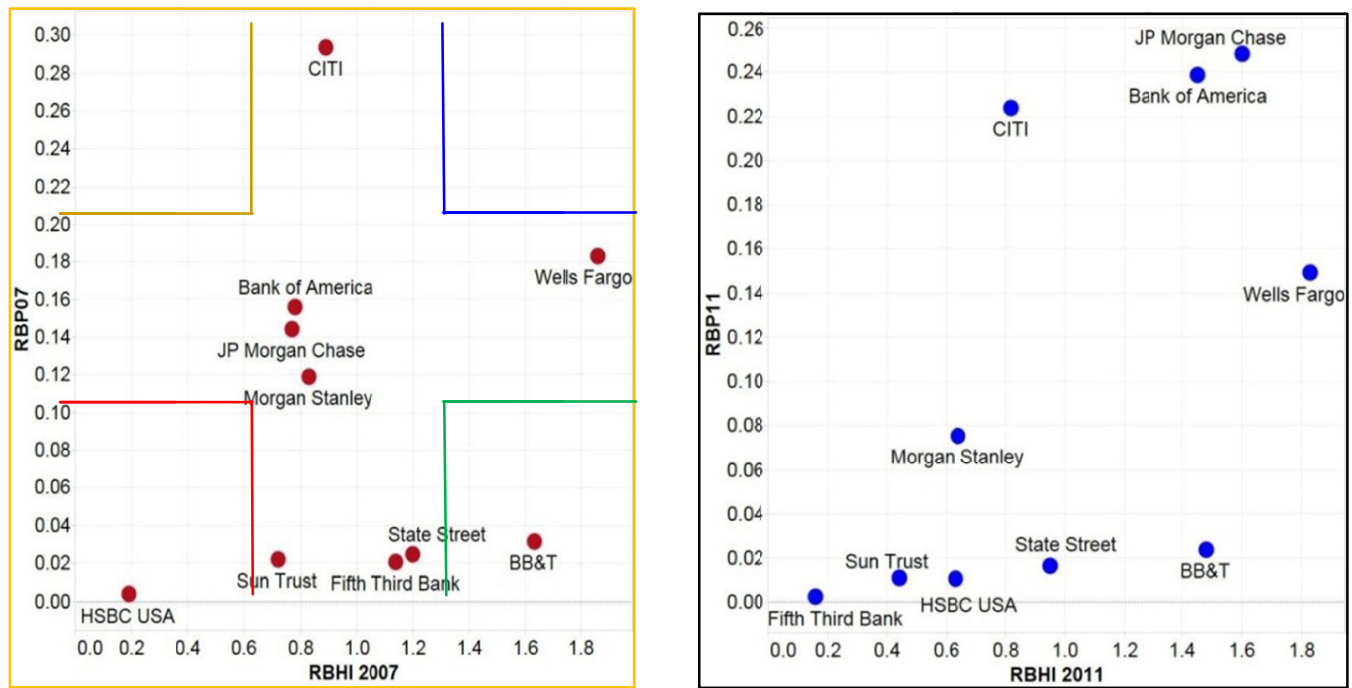

Figure 4. Behavioral brand evaluation typology, banking industry (pre- and post-GFC)

Note. RBP: Relative Brand Powerfulness; RBHI: Relative Brand Health Index.

Looking at the BBE typology in the department stores category shown in Figure 5, however, J C Penny has lost the momentum from 2007 to 2011, but still has the chance to be back on track, by carefully developing effective marketing strategies and actions to fulfil customers' values. Since 2007, it has continued on its current path, and has been dropped to Strugglers from the Disoriented category.
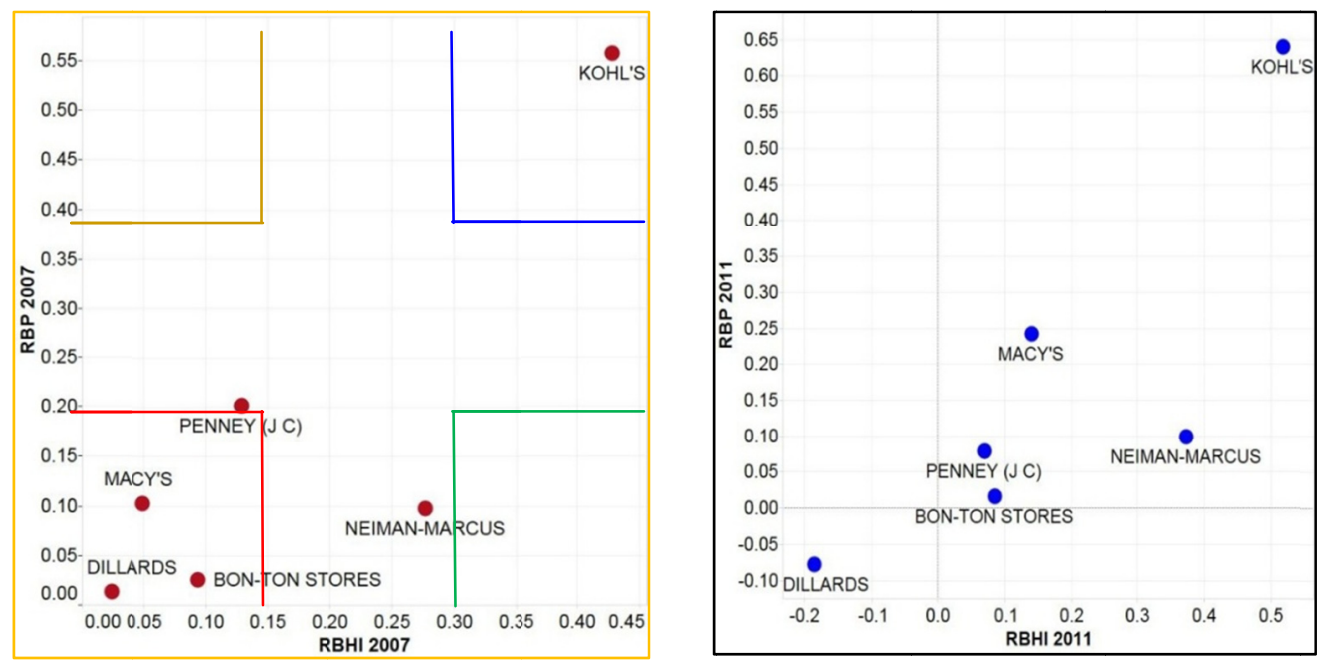

Figure 5. Behavioral brand evaluation typology, department stores (pre- and post-GFC)

Note. RBP: relative brand powerfulness; RBHI: relative brand health index.

In the insurance industry, brands such as Selective, Progressive, and Travellers are among the Emergers and although they are not quite powerful, they have been able to successfully fulfil their target market needs, and experience sustainable growth over the study period. 

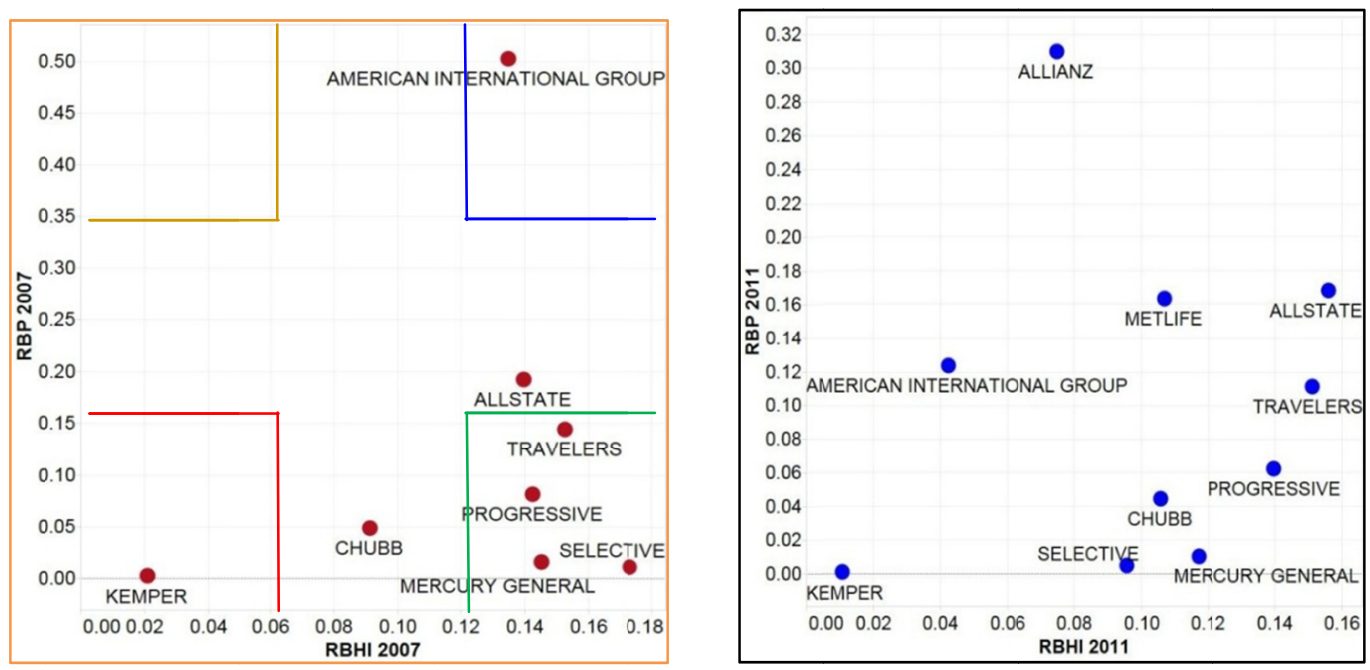

Figure 6. Behavioral brand evaluation typology, insurance industry (pre- and post-GFC)

Note. RBP: Relative Brand Powerfulness; RBHI: Relative Brand Health Index.

Overall, we reviewed the health of brands across airline, banking, department stores and insurance industries. It is evident that brands with a persistent growth and low volatility are the healthiest brands. Such brands have been able to keep their sales growth high over time, despite the seasonal forces such as GFC.

\section{Conclusion}

In this paper, for the first time, a long-term oriented brand evaluation typology was proposed. Depending on the extent to which a brand is healthy and powerful, a brand can be classified into four key categories: Emerger, Dynamo, Disoriented, or Struggler. In each phase a brand should develop and apply different scenarios suitable for that stage in order to stay in or move on towards another stage (unless, of course, it is a Dynamo, i.e. the ultimately desired stage). Emergers need to build their profile and expand their brand, among others. Market penetration and market and product development strategies can be applied to reach and acquire more customers. Emergers should apply growth strategies to move on to the next phase which is Dynamo. Perhaps the main factor which distinguishes Dynamos from Disoriented brands is that brands in the Disoriented category tend to stick to their old-fashioned strategies and actions that have been successful in the past, but may not be effective any more. Sticking to their out-of-date prescriptions to tackle the market challenges, Disoriented brands will soon find themselves in a worse phase of the brand cycle which is Strugglers. For brands in the Struggler category, however, immediate and dramatic action must be taken in order to save the brand. Rebranding, product innovation and service improvements seem unavoidable, yet ultimately Strugglers might become victims of mergers and acquisition strategies that may not work in their stakeholders' interests.

\section{References}

Aaker, D. A. (1991). Managing the brand equity, capitalizing on the value of a brand name. New York: The Free Press.

Ailawadi, K. L., Lehmann, D. R., \& Neslin, S. A. (2003). Revenue premium as an outcome measure of brand equity. Journal of Marketing, 67(4), 1-17. http://dx.doi.org/10.1509/jmkg.67.4.1.18688

Ataman, M. B., Van Heerde, H., \& Mela, C. F. (2010). The long-term effect of marketing strategy on brand sales. Journal of Marketing Research, 47(October), 866-882. http://dx.doi.org/10.1509/jmkr.47.5.866

Bruce, N. I., Peters, K., \& Naik, P. A. (2012). Discovering how advertising grows sales and builds brands. Journal of Marketing Research, 49(December), 793-806. http://dx.doi.org/10.1509/jmr.11.0060

Bureau of Economic Analysis. (2013). Interactive Access to Industry Economic Accounts Data: GDP by Industry. Retrieved

from http://www.bea.gov/iTable/itable.cfm?reqid=51\&step=1\#reqid=51\&step=51\&isuri=1\&5102=5

Cabral, L. M. B. (2000). Stretching firm and brand reputation. The RAND Journal of Economics, 31(4), 658-673.

Christodoulides, G., \& De Chernatony, L. (2010). Consumer-based brand equity conceptualisation and 
measurement. International Journal of Market Research, 52(1), 43-66.

Erdem, T., Swait, J., \& Louviere, J. (2002). The impact of brand credibility on consumer price sensitivity. International Journal of Research in Marketing, 19(1), 1-19. http://dx.doi.org/10.1016/S0167-8116(01)00048-9

Glynn, M. S., Brodie, R. J., \& Motion, J. (2012). The benefits of manufacturer brands to retailers. European Journal of Marketing, 46(9), 1127-1149.

Hanssens, D. M., Rust, R. T., \& Srivastava, R. K. (2009). Marketing strategy and Wall Street: Nailing down marketing's impact. Journal of Marketing, 73, 115-118. http://dx.doi.org/10.1509/jmkg.73.6.115

Holbrook, M. B. (1992). Product quality, attributes, and brand name as determinants of price: The case of consumer electronics. Marketing Letters, 3(1), 71-83. http://dx.doi.org/10.1007/BF00994082

Keller, K. L. (1993). Conceptualizing, measuring and managing customer-based brand equity. Journal of Marketing, 57(1), 1-22. http://dx.doi.org/10.2307/1252054

Keller, K. L. (2013). Strategic Brand Management: Building, Measuring, and Managing Brand Equity (4th ed.). London: Pearson Education.

Keller, K. L., \& Lehmann, D. R. (2006). Brands and branding: Research findings and future priorities. Marketing Science, 25(6), 740-759. http://dx.doi.org/10.1287/mksc.1050.0153

Keller, K. L., \& Lehmann, D. R. (2009). Assessing long-term brand potential. Journal of Brand Management, 17, 6-17. http://dx.doi.org/10.1057/bm.2009.11

Kumar, V., Dalla Pozza, I., \& Ganesh, J. (2013) Revisiting the satisfaction-loyalty relationship: Empirical generalizations and directions for future research. Journal of Retailing, 89(3), 246-262. http://dx.doi.org/10.1016/j.jretai.2013.02.001

Lodish, L. M., \& Mela, C. F. (2007). If brands are built over years, why are they managed over quarters? Harvard Business Review, 85(7/8), 104-112.

Madden, T. J., Fehle, F., \& Fournier, S. (2006). Brands matter: An empirical demonstration of the creation of shareholder through branding. Journal of Academy of Marketing Science, 34(2), 224-235. http://dx.doi.org/10.1177/0092070305283356

Mirzaei, A., Gray, D., \& Baumann, C. (2011). Developing a new model for tracking brand equity as a measure of $\begin{array}{llll}\text { marketing } & \text { effectiveness. The Marketing }\end{array}$ http://dx.doi.org/10.1362/146934711X13210328715821

Mirzaei, A., Gray, D., Baumann, C., Johnson, L. W., \& Winzar, H. (2015). A behavioural long-term based measure to monitor the health of a brand. Journal of Brand Management, 22(4), 299-322. http://dx.doi.org/10.1057/bm.2015.18

Mizik, N., \& Jacobson, R. (2007). Myopic marketing management: Evidence of the phenomenon and its long-term performance consequences in the SEO context. Marketing Science, 26(3), 361-379. http://dx.doi.org/10.1287/mksc.1060.0261

Mizik, N., \& Jacobson, R. (2009). Valuing branded businesses. Journal of Marketing, 73, 137-153. http://dx.doi.org/10.1509/jmkg.73.6.137

Park, C. S., \& Srinivasan, V. (1994). A survey-based method for measuring and understanding brand equity and its extendibility. Journal of Marketing Research, 31(2), 271-288. http://dx.doi.org/10.2307/3152199

Shankar, V., Azar, P., \& Fuller, M. (2008). Practice Prize Paper-BRANEQT: A Multicategory Brand Equity Model and Its Application at Allstate. Marketing Science, 27(4), 567-584. http://dx.doi.org/10.1287/mksc.1070.0320

Tiwari, M. K. (2010). Separation of brand equity and brand value. Global Business Review, 11(3), 421-434. http://dx.doi.org/10.1177/097215091001100307

\section{Copyrights}

Copyright for this article is retained by the author(s), with first publication rights granted to the journal.

This is an open-access article distributed under the terms and conditions of the Creative Commons Attribution license (http://creativecommons.org/licenses/by/3.0/). 